rapid readout BIs were negative at the predicted adequate time). In addition, all rapid readout BIs were positive at the minimum exposure time, and in no instance was there a negative fluorescent result and a positive visible color change result in the same BI, which would indicate a false negative result. Thus, BIs based on enzyme detection are capable of providing a more sensitive indication of sterilization cycle failure than currently available spore growth BIs in a much shorter time and without any apparent disadvantages.

\section{REFERENCES}

1. Association of Operating Room Nurses. Proposed recommended practices for sterilization in the practice setting. AORN $J$ 1994;52:109-120.

2. Joint Commission on Accreditation of Healthcare Organizations. A ccreditation Manual for Hospitals. Oakbrook Terrace, IL: Joint Commission on Accreditation of Healthcare Organizations; 1994.

3. American Society for Healthcare Central Service Personnel of the American Hospital Association. I\& commended Practice for Central Service, Sterilization. Chicago, IL American Hospital Association; 1989.

4. Association for the Advancement of Medical Instrumentation. Good Hospital Practice: Steam Sterilization and Sterility Assurance. Arlington, VA: AAMI; 1993.

5. Gamer JS, Favero MS. Guidelines for $\mathrm{H}$ andwashing and Environmental Control. CDC Publication No. 85923404. Atlanta, GA: Centers for Disease Control; 1985.

6. Vesley D, Langholz AC, Rohlfing SR, Foltz WE. Fluorimetric detection of a Bacillus stearothermophilus spore-bound enzyme, $\alpha$-D-glucosidase, for rapid identification of flash sterilization failure. Appl Environ Microbiol 1992;58:717-719.

7. Rutala WA, Gergen MF: Weber DJ. Evaluation of a rapid readout biological indicator for flash sterilization with three biological indicators and three chemical indicators. Infect Control Hosp Epidemiol 1993;14:390-394.

8. Association for the Advancement of Medical Instrumentation (AAMD). American N ational Standard for Biological Indicators for Saturated Steam Sterilization Processes in Health Care Facilities, ST 19. Arlington, VA: AAMI; 1986.

\title{
TB Cases Decline in New York City for Second Year in a Row
}

\section{by Gina Pugliese, RN, MS Medical News Editor}

New York City officials reported that tuberculosis (TB) was on the decline in the five boroughs of the city.
The incidence of TB has dropped from 3,235 cases in 1993 to 2,995 cases in 1994, representing a $7.4 \%$ decline from 3,811 cases in 1992. New York City Mayor Rudolph Giuliani warned that New York City still has the highest number of TB cases in the country, and it cannot afford to slow down its efforts to control the disease.

FROM: Jones C. TB cases decline, city says. New Y ork Times. March 14, 1995;B1. 